DOI : https://doi.org/10.24123/jbt.v5i1.3931

\title{
DESAIN APLIKASI LAPORAN KEUANGAN USAHA KOS- KOSAN BERDASARKAN SAK EMKM MENGGUNAKAN MICROSOFT ACCESS
}

\author{
Joseph Nugraha Tangon ${ }^{1}$, Merry Ligia Sael ${ }^{2}$, Ririn Fadilah Baso ${ }^{3}$ \\ $1,2,3$ \\ Jurusan Akuntansi/Politeknik Negeri Manado; 081233433724 \\ Email : joseph.tangon@ gmail.com ${ }^{1}$, merrysael@gmail.com
}

\begin{abstract}
The purpose of this study was to design existing financial reports using applications that are easier, faster, more complete, accurate, and timely in presenting financial statement information. This research was conducted at the Kost Katto 2 Kec. Mapanget, Manado. The data obtained from the author's interviews with business owners and employees. The research method used was a qualitative method with a descriptive approach. Data collection was carried out by means of observation, interviews, and literature study.The results showed that in preparing financial reports based on SAK EMKM using Microsoft Access, all difficulties and problems faced in preparing financial reports could be resolved. This arrangement was based on the accounting cycle by preparing the required forecast tables, after which it can input transactions and can see the results of the financial statement design in the form of an income statement, a statement of financial position, and notes to financial statements. The recommendation from the results of this study is that Kost Katto 2 should make bookkeeping reports in accordance with existing standards and make financial reports using the Microsoft Access application program designed based on SAK EMKM
\end{abstract}

Keywords: Application design, financial report, SAK EMKM

\section{Pendahuluan}

Kegiatan Usaha Mikro, Kecil, dan Menengah (UMKM) merupakan salah satu bidang usaha yang dapat berkembang dan konsisten dalam perekonomian Indonesia saat ini khususnya di kota Manado. Tetapi yang menjadi permasalahan UMKM pada saat ini umumnya terletak pada sumber daya manusia, modal, pemahaman dalam pembuatan laporan keuangan dan penguasaan teknologi modern.

Pada dasarnya Usaha Kos kosan ini tergolong pekerjaan yang mudah tetapi memiliki tingkat pendapatan yang tinggi. Seperti yang kita lihat saat ini sedang maraknya usaha kos-kosan di berbagai tempat dan yang menjadi sasaran utama adalah para mahasiswa, pekerja sampai keluarga yang berasal dari luar daerah. Usaha ini juga dapat menyediakan persediaan kamar yang kecil dan minim fasilitas sampai kamar yang besar dengan fasilitas layaknya hotel. 
Untuk menunjang kelangsungan usaha dan mendapatkan informasi mengenai kemajuan dan keuntungan usaha ini, maka sangat penting untuk menyusun sebuah laporan keuangan. Dalam laporan keuangan minimal memuat laporan posisi keuangan dan laporan laba rugi usaha. Terkait dengan jenis usaha kos-kosan yang termasuk dalam kategori UMKM, maka diperlukan suatu standar laporan keuangan yang bisa mengakomodir aktivitas dan akun-akun yang diperlukan dalam usaha UMKM. Standar laporan keuangan yang bisa digunakan dalam menyusun laporan keuangan usaha koskosan adalah SAK EMKM. SAK EMKM hanya memuat laporan posisi keuangan, laporan rugi laba, dan catatan atas laporan keuangan sehingga sangat cocok untuk digunakan dalam UMKM.

Berdasarkan data dari Dinas Pendapatan Daerah Kota Manado, 2020 jumlah usaha kos di kota Manado sebanyak 1320 rumah kos yang belum menerapkan SAK EMKM. Pencatatan yang dilakukan hanya sebatas pemasukan dan pengeluaran saja, sehingga UMKM kos-kosan sulit mendapatkan pembiayaan dari perbankan dan sumber pendanaan lainnya karena tidak memiliki laporan keuangan yang sesuai dengan standar yang berlaku. Oleh karena itu dengan semakin berkembangnya usaha, menuntut UMKM koskosan untuk menyediakan laporan keuangan yang sesuai dengan standar yang berlaku, karena Laporan keuangan tidak hanya bertujuan memberikan informasi terkait dengan pemasukan dan pengeluaran saja, tetapi juga bertujuan untuk menganalisis kinerja keuangan yang dapat memberikan informasi tentang posisi keuangan, kinerja, arus kas dan jumlah pembayaran pajak yang harus di bayarkan. Selain itu juga dengan adanya laporan keuangan dapat memudahkan usaha kos-kosan untuk memperoleh kredit bank dalam rangka mengembangkan usahanya.

Berdasarkan latar belakang yang ada, maka permasalahan dalam penelitian ini dirumuskan yaitu bagaimana mendesain Aplikasi Laporan Keuangan Berdasarkan SAK EMKM menggunakan Microsoft Access? Adapun tujuan dalam penelitian ini adalah untuk mendesain Laporan Keuangan menggunakan Microsoft Access berdasarkan SAK EMKM.

\section{Landasan Teori}

Akuntansi merupakan suatu proses dalam mengidentifikasikan, mengukur dan melaporkan informasi ekonomi dengan tujuan memungkinkan adanya penilaian dan keputusan yang jelas dan tegas untuk mereka yang memakai informasi tersebut. (Soemarsono, 2004)

\section{Siklus Akuntansi}

Dalam proses menghasilkan informasi yang dibutuhkan oleh berbagai pihak yang berkepentingan, akuntansi harus melewati beberapa tahapan proses. Proses tersebut dimulai dari mengumpulkan dokumen dasar transaksi, mengklasifikasikan jenis transaksi, menganalisis, meringkasnya dalam catatan, hingga melaporkannya dalam bentuk laporan keuangan yang dibutuhkan, yang disebut Siklus Akuntansi. 


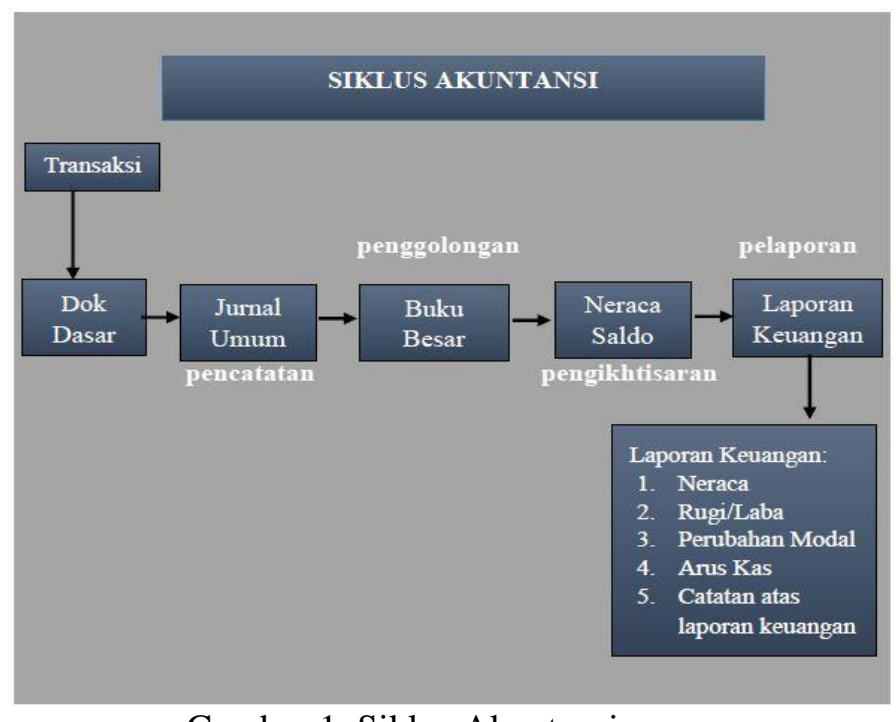

Sumber: Data Olahan 2020

\section{Laporan Keuangan}

Laporan Keuangan menurut PSAK No.1 (2015: 1.3) adalah suatu penyajian terstruktur dari posisi keuangan dan kinerja keuangan suatu entitas. Tujuan laporan keuangan adalah memberikan informasi mengenai posisi keuangan, kinerja keuangan, dan arus kas entitas yang bermanfaat bagi sebagian besar kalangan pengguna laporan keuangan dalam pembuatan keputusan ekonomi. Laporan keuangan juga menunjukkan hasil pertanggungjawaban manajemen atas penggunaan sumber daya yang dipercayakan kepada mereka. Dalam rangka mencapai tujuan tersebut, laporan keuangan menyajikan informasi mengenai entitas yang meliputi:

a. Aset

b. Liabilitas

c. Ekuitas

d. Penghasilan dan beban termasuk keuntungan dan kerugian

e. Kontribusi dari dan distribusi kepada pemilik dalam kapasitasnya sebagai pemilik.

f. dan arus kas

Laporan Keuangan Berdasarkan Standar Akuntansi Keuangan Entitas Mikro Kecil dan Menengah (SAK EMKM) mensyaratkan laporan keuangan yang disajikan Usaha mikro kecil dan menengah (UMKM) terdiri dari Laporan posisi keuangan, Laporan laba rugi dan Catatan atas laporan keuangan (CALK) yang bertujuan untuk memudahkan suatu entitas dalam mengungkapkan informasi keuangan dan non keuangannya.

\section{Usaha Mikro Kecil Menengah (UMKM)}

UMKM diatur berdasarkan Undang-Undang Nomor 20 tahun 2008 tentang Usaha Mikro Kecil dan Menengah. Secara umum ciri ciri UMKM adalah : manajemen berdiri sendiri, modal disediakan sendiri, daerah pemasarannya lokal, aset perusahaannya kecil, dan jumlah karyawan yang dipekerjakan terbatas. Asas pelaksanaan UMKM adalah kebersamaan, ekonomi yang demokratis, kemandirian, keseimbangan kemajuan, berkelanjutan, efesiensi, keadilan, serta kesatuan ekonomi nasional. Untuk membedakan sebuah usaha apakah itu termasuk usaha mikro, usaha kecil, atau usaha menengah, oleh pemerintah diberikan batasan berdasarkan undang-undang sesuai dengan kriteria jenis usaha. 
Menurut Undang-Undang Nomor 20 tahun 2008 tentang Usaha Mikro, Kecil, Dan Menengah pada Pasal 6, kriteria UMKM sebagai berikut :

1) Kriteria Usaha Mikro adalah sebagai berikut:

a. memiliki kekayaan bersih paling banyak Rp50.000.000,00 (lima puluh juta rupiah) tidak termasuk tanah dan bangunan tempat usaha; atau

b. memiliki hasil penjualan tahunan paling banyak Rp300.000.000,00 (tiga ratus juta rupiah).

2) Kriteria Usaha Kecil adalah sebagai berikut:

a. memiliki kekayaan bersih lebih dari Rp50.000.000,00 (lima puluh juta rupiah) sampai dengan paling banyak Rp500.000.000,00 (lima ratus juta rupiah) tidak termasuk tanah dan bangunan tempat usaha; atau

b. memiliki hasil penjualan tahunan lebih dari Rp300.000.000,00 (tiga ratus juta rupiah) sampai dengan paling banyak Rp2.500.000.000,00 (dua milyar lima ratus juta rupiah).

3) Kriteria Usaha Menengah adalah sebagai berikut:

a. memiliki kekayaan bersih lebih dari Rp500.000.000,00 (lima ratus juta rupiah) sampai dengan paling banyak Rp10.000.000.000,00 (sepuluh milyar rupiah) tidak termasuk tanah dan bangunan tempat usaha; atau

b. memiliki hasil penjualan tahunan lebih dari Rp2.500.000.000,00 (dua milyar lima ratus juta rupiah) sampai dengan paling banyak Rp50.000.000.000,00 (lima puluh milyar rupiah).

\section{Penggunaan Access dalam Akuntansi}

Microsoft Access adalah program berbasis data komputer, bisa digunakan untuk keperluan tertentu baik keperluan perkantoran ataupun perorangan. Microsoft Access merupakan salah satu software pengolah database yang dapat mengolah berbagai jenis data serta membuat hasil akhir berupa laporan dengan tampilan yang menarik, mudah dipahami dan menjadi salah satu software pengolah database yang sangat populer karena sudah diakui kecanggihannya (Asriyani, 2019).

Berikut ini kelebihan yang dimiliki Microsoft Access 2019, yaitu:

1. Microsoft Access memberikan kemudahan dalam pengoperasian softwarenya. Berbagai wizard dan template form, query, report, disediakan untuk digunakan dan dimodifikasi dengan mudah.

2. Dengan menggunakan Microsoft Access, kita dapat menyusun relasi antar tabel dengan mudah. Dengan fitur yang disediakan akan mempermudah kegiatan dalam membuat skema relasi dan SQL table.

3. Aplikasi Microsoft Access terintegrasi dengan aplikasi Microsoft Visual Basic terutama Visual Basic 6.0. Memang kebanyakan database Ms Access dibangun dengan Microsoft Visual Basic 6.0. 23

4. Database MDB dikenal dengan proteksi keamanan file basis datanya. Password disediakan untuk pengamanan file basis data agar tidak bisa dibuka kecuali mengetahui passwordnya.

5. Microsoft Acesss mendukung penyimpanan basis data dengan jumlah yang cukup besar. 6. Microsoft Acesss menyediakan fitur Query Design Grid, program berbasis visual untuk query SQL tanpa harus memahami pemrograman SQL

(Asriyani, 2019) 
Salah satu cara mengotomatiskan proses akuntansi yang cukup panjang adalah dengan memanfaatkan fitur-fitur yang ada dalam Microsoft Access yaitu mengkorelasikan antara tabel, query, form dan report untuk menghasilkan laporan keuangan yang prosesnya lebih praktis dari pada pencatatan manual.

\section{Kerangka Konsep Penelitian}

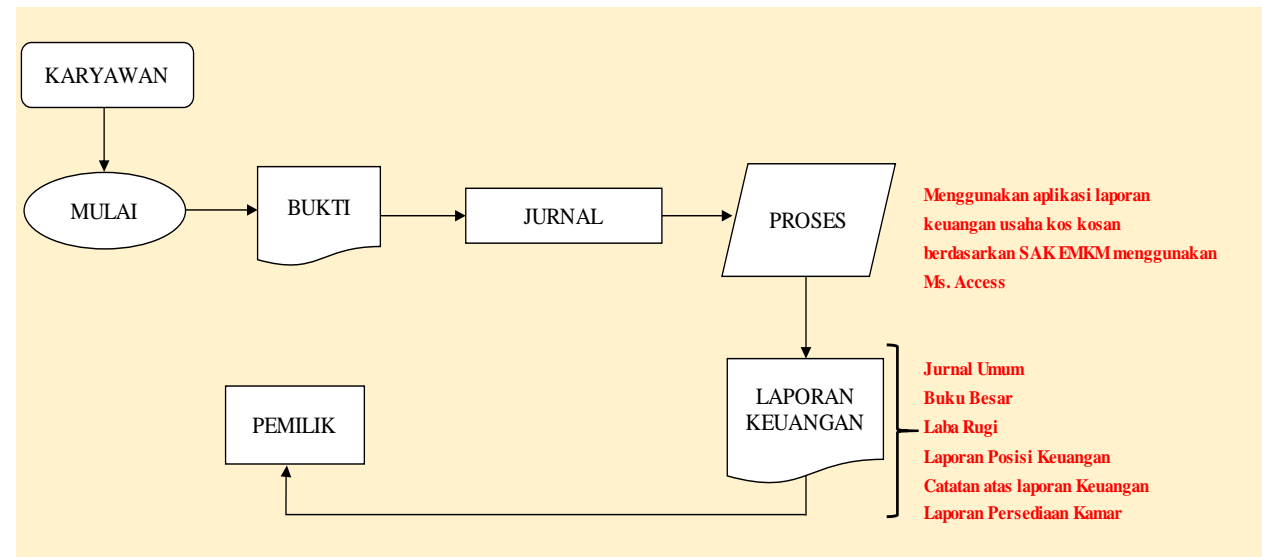

Gambar 2. Kerangka Konsep Penelitian

Sumber: Data Olahan 2020

Metode Penelitian

Peneliotian ini dapat dimasukkan dalam kategori penelitian disain model. Jadi, urutannya adalah identifikasi masalah, merancang model dan mengevaluasi untuk melihat model yang dirancang sudah benar.

\section{Hasil Penelitian}

Hasil penelitian menunjukkan bahwa pencatatan yang dilakukan adalah catatan sederhana yang hanya menuliskan kas masuk dan kas keluar saja sehingga pemilik mengaku kesulitan dalam mengetahui keuntungan dan kerugian yang dialami setiap bulannya secara detail.

Berdasarkan uraian diatas didesain laporan keuangan usaha kos-kosan agar sesuai dengan standar akuntansi keuangan yang berlaku yaitu SAK EMKM dengan menggunakan Microsoft Access. Proses pencatatan tersebut dilakukan dengan cara mencatat transaksi kedalam jurnal, posting ke buku besar, sampai akhir periode pencatatan. Adanya proses tersebut akan menghasilkan laporan keuangan yang terdiri dari laporan posisi keuangan, laporan laba rugi dan catatan atas laporan keuangan.

\section{Desain Aplikasi Laporan Keuangan berdasarkan SAK EMKM pada usaha kos- kosan Menggunakan Microsoft Access}

1. Menu Utama

Menu utama digunakan sebagai tampilan awal aplikasi laporan keuangan. Menu utama ini dapat digunakan oleh admin untuk menampilkan data yang diinginkan dengan tujuan untuk mempermudah pemilik dalam membuka data yang ingin digunakan. 


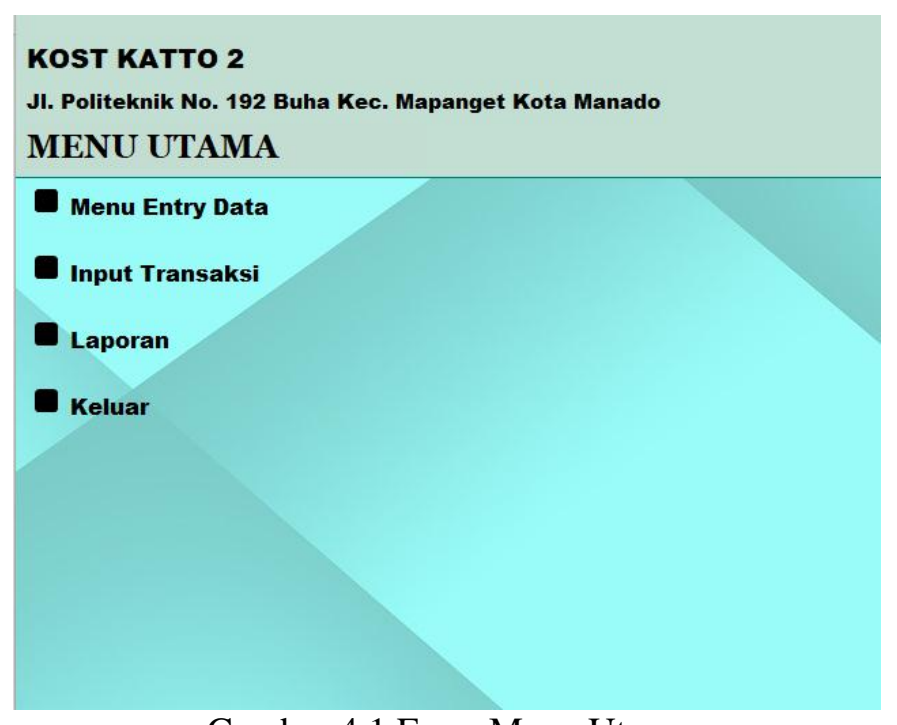

Sumber: Data Olahan, 2020

\section{Desain Kode akun dan Nama Akun}

Kode akun dan nama akun merupakan sebuah daftar dari akun-akun entitas yang digunakan untuk mengidentifikasi ataupun memperlancar proses pencatatan transaksi, baik itu pemasukan atau pengeluaran. Kode akun dan nama akun ini dapat disusun sesuai dengan kebutuhan Entitas.

Pada Kost Katto 2 belum memiliki daftar kode akun yang sesuai dengan kebutuhan, selanjutnya berdasarkan data yang diperoleh oleh penulis pada saat melakukan penelitian dan juga menganalisis transaksi yang biasanya terjadi di Kost Katto 2 secara umum, maka dari data tersebut digunakan sebagai dasar dalam penyusunan daftar perkiraan.

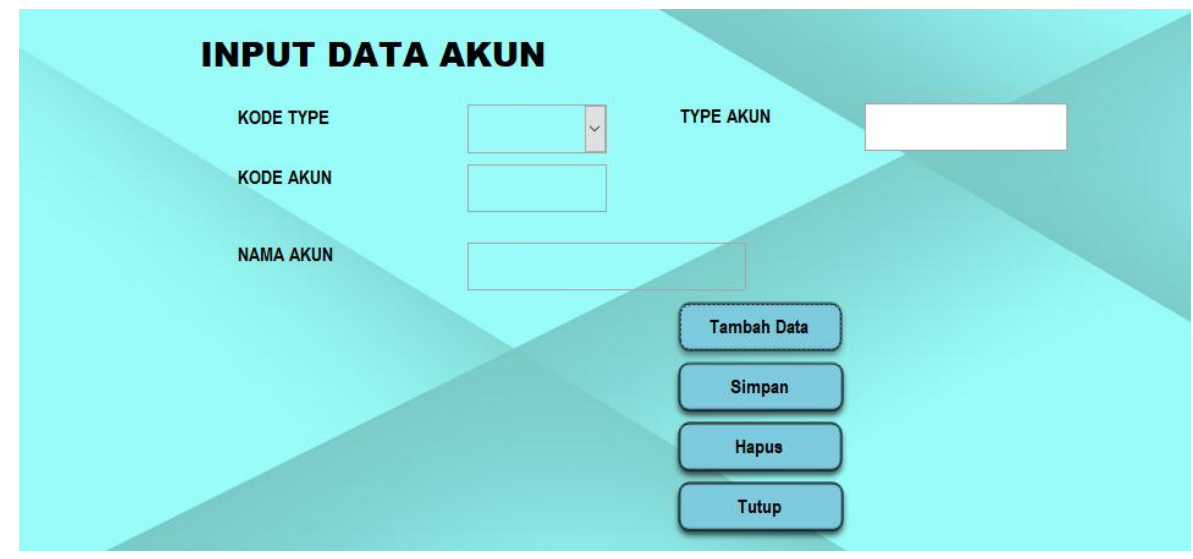

Gambar 4.2 Form input data Akun

Sumber: Data Olahan, 2020

Untuk membuat form data akun, maka harus dibuat terlebih dahulu tabel data akun, kemudian membuat query data akun. Query data akun diperlakukan untuk menghubungkan informasi data akun dengan query lainya seperti query jurnal.

3. Saldo Awal Akun

Untuk memulai suatu periode akuntansi dibutuhkan saldo awal sebagai dasar penyusunan laporan keuangan periode selanjutnya. Saldo awal biasanya merupakan saldo dari akhir 
periode akuntansi suatu entitas sebelumnya dan menjadi saldo awal di periode akuntansi selanjutnya.

Setelah data akun dibuat maka langkah selanjutnya yaitu membuat neraca saldo awal untuk mengetahui nilai-nilai pada Aset, Liabilitas, dan Ekuitas pada awal periode.

Saldo awal akun yang sudah diinput bisa dilihat pada tabel saldo awal akun.

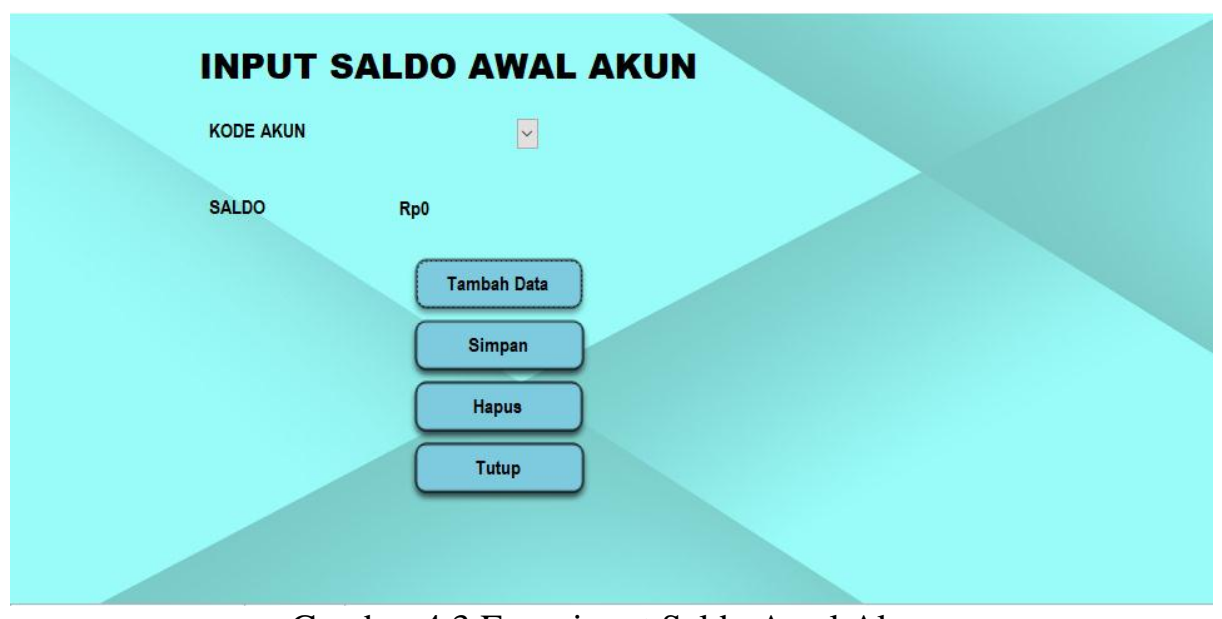

Gambar 4.3 Form input Saldo Awal Akun

Sumber: Data, Olahan 2020

Untuk membuat form saldo awal akun, maka harus dibuat tabel saldo awal akun dan query saldo awal. Tabel saldo awal akun akan menyimpan data-data yang di input dari form saldo awal akun dengan tabel lain yang membutuhkan informasi mengenai saldo awal akun tersebut.

4. Jurnal Transaksi

Jurnal transaksi ini digunakan untuk mencatat transaksi keuangan Kost Katto secara kronologis dengan menyebutkan akun yang didebet maupun akun yang dikredit.

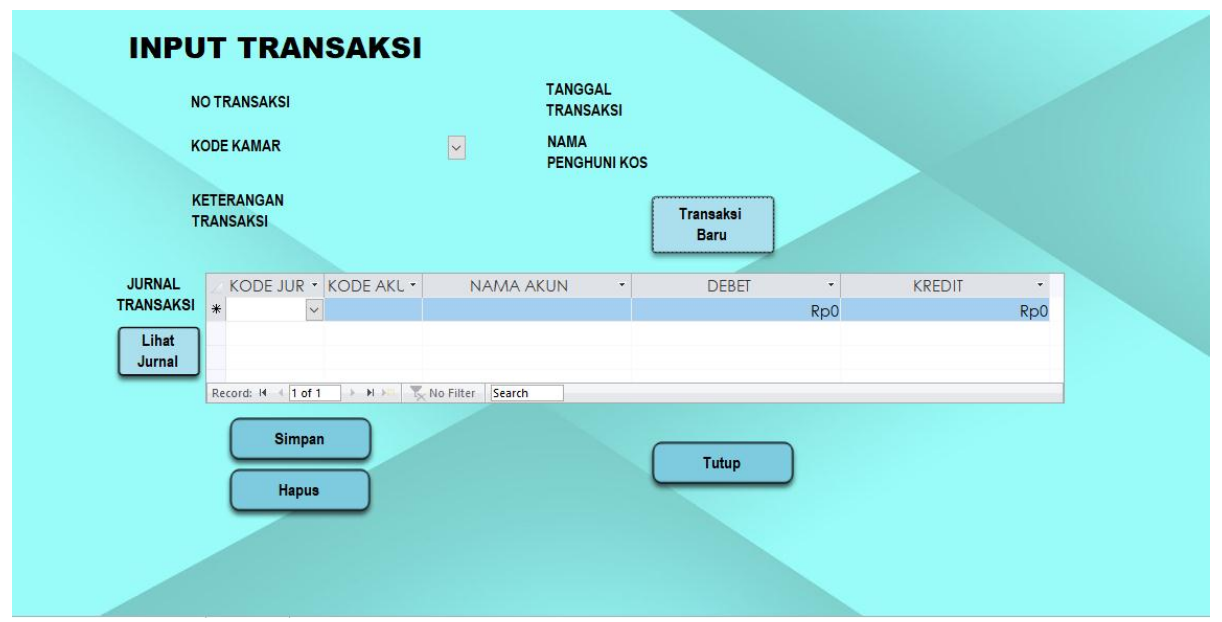

Gambar 4.4 Form Input Transaksi dan Jurnal Transaksi

Sumber: Data Olahan, 2020 


\begin{tabular}{|c|c|c|c|c|c|}
\hline & & Politeknik N & $\begin{array}{l}\text { KOST KATTO } 2 \\
192 \text { Buha Kec. Map: } \\
\text { JURNAL } \\
\text { riode Maret } 2020\end{array}$ & Manado & \\
\hline NO & KETERANGAN TRANSAKSI & KODE KAMAR & NAMA AKUN & DEBET & KREDIT \\
\hline 01 & Pengeluaran ibadah & - & Beban Ibadah & Rp150.000 & Rp0 \\
\hline 01 & Pengeluaran ibadah & - & Kas & Rpo & Rp150.000 \\
\hline 02 & Beban gaji & - & Beban Gaji & Rp5.500.000 & Rpo \\
\hline 02 & Beban gaji & - & Kas & Rpo & Rp5.500.000 \\
\hline 03 & Pembayaran iuran sampah & - & Beban Sampah & Rp100.000 & Rpo \\
\hline 03 & Pembayaran iuran sampah & - & Kas & Rpo & Rp100.000 \\
\hline 04 & Pembelian plastik sampah & - & Beban Perlengkapan & Rp675.000 & Rpo \\
\hline 04 & Pembelian plastik sampah & - & Kas & Rpo & Rp675.000 \\
\hline 05 & Pembelian gas & - & Beban Perlengkapan & Rp18.000 & Rpo \\
\hline 05 & Pembelian gas & - & Kas & Rpo & Rp18.000 \\
\hline 06 & Pembayaran kos & AL01 & Kas & Rp1.500.000 & Rpo \\
\hline 06 & Pembayaran kos & AL01 & Pendapatan & Rpo & Rp1.500.000 \\
\hline 07 & Pembayaran kos & AL02 & Kas & Rp1.250.000 & Rpo \\
\hline 07 & Pembayaran kos & AL02 & Pendapatan & Rpo & Rp1.250.000 \\
\hline
\end{tabular}

Gambar 4.5 Tampilan Jurnal Transaksi

Sumber: Data Olahan, 2020

Untuk membuat Jurnal Transaksi, langkah-langkah yang dilakukan adalah, Tambahkan tabel jurnal transaksi pada saat Form Wizard melalui Available Fields dan Selected Fields, Tambahkan fields kode jurnal, no transaksi, kode akun, nama akun, debet, dan kredit, dan yang terakhir Jurnal transaksi akan menjadi subform karena di desain bersamaan dengan Form Transaksi.

\section{Buku Besar}

Buku besar adalah kumpulan dari semua akun yang menunjukan nilai saldo dari tiap-tiap akun tersebut. Berdasarkan transaksi-transaksi yang telah diinput pada form transaksi maka akan didapatkan buku besar yang terdapat saldo dari masing-masing akun yang ada di Kos Katto 2.

\begin{tabular}{|c|c|c|c|c|}
\hline \multicolumn{5}{|c|}{$\begin{array}{c}\text { KOST KATTO } 2 \\
\text { JI. Politeknik No. } 192 \text { Buha Kec. Mapanget Kota Manado } \\
\text { BUKU BESAR } \\
\text { Periode Maret } 2020\end{array}$} \\
\hline NO TRANSAKSI & KETERANGAN TRANSAKSI & DEBET & KREDIT & SALDO_AKUN \\
\hline 01 & Pengeluaran ibadah & Rpo & Rp150.000 & -Rp150.000,00 \\
\hline 02 & Beban gaji & Rpo & Rp5.500.000 & -Rp5.500.000,00 \\
\hline 03 & Pembayaran iuran sampah & Rpo & Rp100.000 & $-R p 100.000,00$ \\
\hline 04 & Pembelian plastik sampah & Rpo & Rp675.000 & $-R p 675.000,00$ \\
\hline 05 & Pembelian gas & Rpo & Rp18.000 & -Rp18.000,00 \\
\hline 06 & Pembayaran kos & Rp1.500.000 & Rpo & Rp1.500.000,00 \\
\hline
\end{tabular}

Gambar 4.6 Tampilan Buku Besar Microsoft Access

Sumber: Data Olahan, 2020

Untuk membuat Buku Besar, langkah-langkah yang dilakukan adalah buat query buku besar dan report buku besar.

\section{Laporan Keuangan}

Laporan Keuangan Kos Katto 2 masih sebatas pencatatan sederhana seperti yang sudah dijelaskan diatas. Sehingga Entitas ini belum menyajikan laporan keuangan yang sesuai dengan SAK EMKM. Maka desain laporan keuangan Kos Katto 2 yang telah penulis buat 
akan berdasarkan SAK EMKM. Laporan keuangan tersebut terdiri dari Laporan posisi Keuangan, Laporan Laba Rugi dan Catatan atas Laporan Keuangan (CALK)

a. Laporan Posisi Keuangan

Laporan posisi keuangan mencakup akun-akun aset, liabilitas, dan ekuitas. Transaksitransaksi yang berhubungan dengan aset, liabilitas, dan ekuitas yang telah di input dalam form transaksi nantinya akan tersaji dalam laporan posisi keuangan.

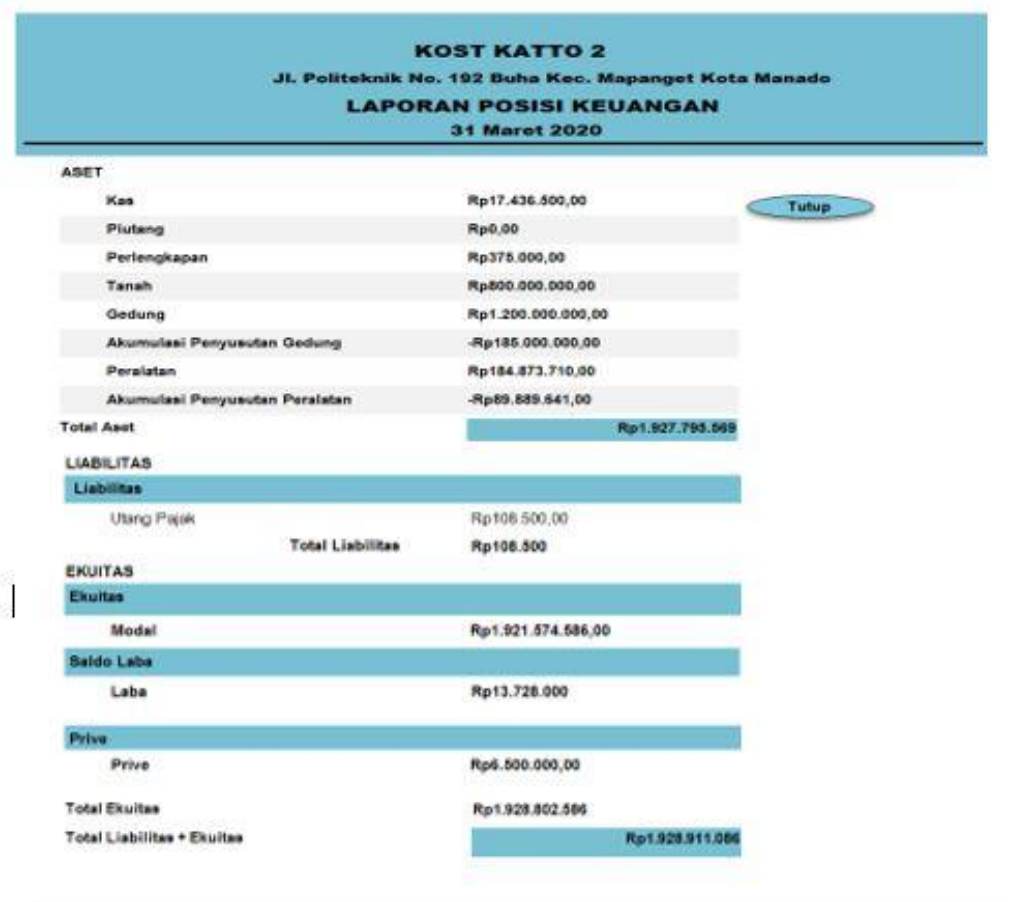

Sumber: Data Olahan, 2020

Gambar 42 Tampilan laporan posisi keuangan

Untuk membuat laporan posisi keuangan langkah-langkah yang dilakukan adalah, membuat query aktiva, hutang, modal akhir, saldo laba dan prive. Kemudian pilih Report Wizard agar bisa menampilkan query tersebut menjadi subreport, selanjutnya subreport yang telah ada di buat menjadi satu laporan.

b. Laporan Laba/Rugi

Laporan laba rugi mencakup pos-pos yaitu pendapatan, dan beban. Penyajian laporan laba rugi dengan menggunakan Microsft Access dimulai dengan menjurnal transaksi penjualan pada form input transaksi yang sudah disajikan, serta menghitung beban-beban yang terjadi dean setelah itu secara otomatis akan menjadi laporan laba rugi 


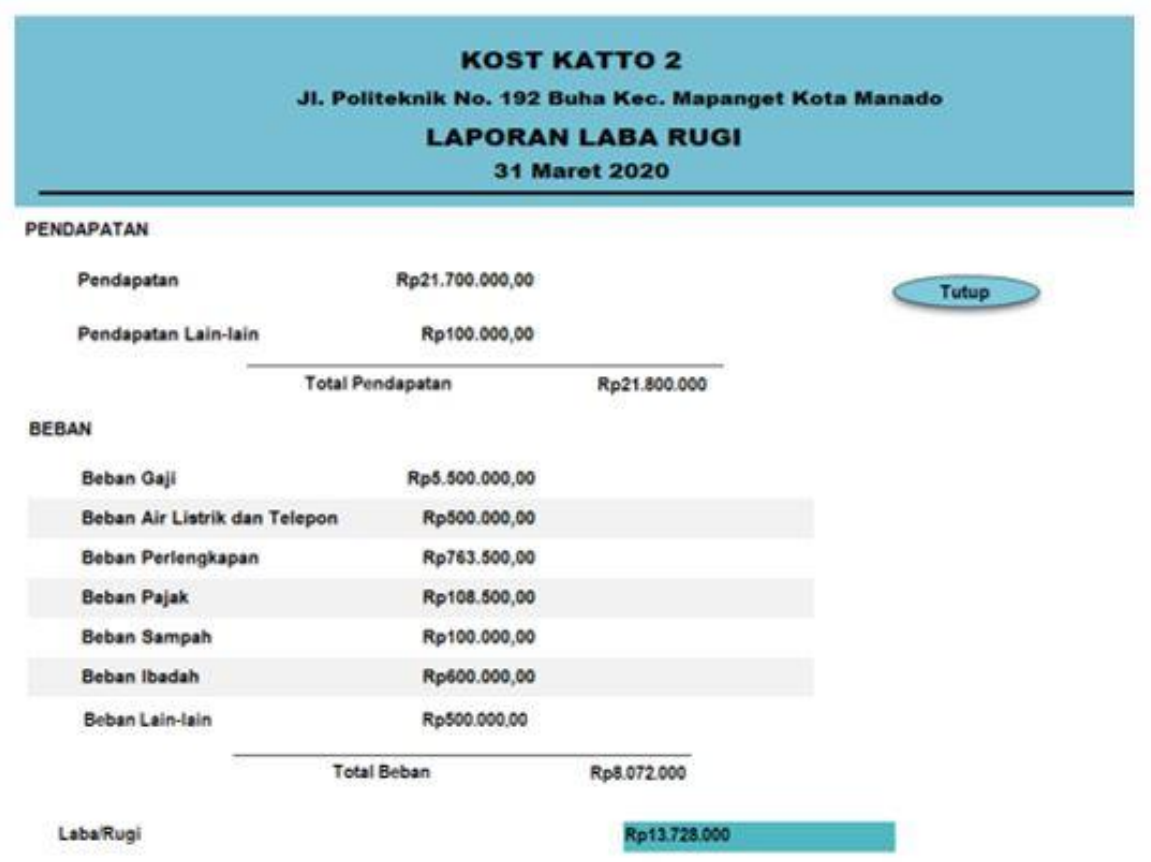

Gambar 4.3 Tampilan laporan laba rugi

Sumber: Data Olahan, 2020

c. Catatan Atas Laporan Keuangan

Catatan atas laporan keuangan adalah bagian dari laporan keuangan yang menyajikan informasi tentang penjelasan atau nilai dari suatu akun tertentu. Karena memuat informasi mengenai suatu akun. Maka informasi-informasi yang nantinya akan dimuat dalam catatan atas laporan keuangan di input terpisah pada form CALK. Setelah itu, hasilnya dapat terlihat dalam report Catatan Laporan Keuangan.

Untuk membuat catatan atas laporan keuangan langkah-langkah yang dilakukan adalah, membuat query Umum, ikhtisar kebijakan, Kas, piutang data CALK, saldo laba, pendapatan, pendapatan lain-lain, beban, dan beban lain-lain. Kemudian pilih Report Wizard agar bisa menampilkan query tersebut menjadi subreport, selanjutnya subreport yang telah ada di buat menjadi satu laporan.

\section{Simpulan}

Pencatatan Laporan Keuangan yang ada pada usaha kos-kosan meliputi catatan kas masuk dan kas keluar saja. Hal ini masih belum sesuai dengan SAK EMKM yang disebutkan bahwa laporan keuangan UMKM minimal terdiri dari : Laporan laba rugi, Laporan posisi keuangan, dan Catatan atas laporan keuangan. Desain aplikasi laporan keuangan Kos Katto 2 menggunakan Microsoft Access berdasarkan SAK EMKM adalah laporan laba rugi yang merupakan evaluasi kinerja usaha yang membuat pemilik mengetahui bagaimana kinerja usahanya dalam satu periode. Laporan posisi keuangan mencerminkan keadaan usaha yang sebenarnya sehingga pemilik dapat mengambil keputusan keuangan yang tepat. Catatan atas laporan keuangan mengungkapkan penjelasan lebih lanjut mengenai akun-akun yang ada pada laporan laba rugi dan laporan posisi keuangan. Dalam desain Aplikasi Microsoft Access ini, dilakukan dengan menggunakan tabel daftar akun, tabel saldo awal dan tabel tabel perkiraan lainnya yang sudah menggunakan rumus pada Microsoft Access untuk keperluan laporan keuangan. Dalam desain Aplikasi pada Microsoft Access ini disesuaikan dengan kebutuhan entitas 
yang merupakan usaha jasa, dengan menggunakan aplikasi ini juga dapat mempermudah pemilik usaha dalam pengelolaan keuangan yang akan dilakukan

\section{Rekomendasi}

Mengingat keterbatasan dalam penelitian ini yang hanya menggunakan satu objek. Disarankan bagi peneliti selanjutnya dapat menemukan objek yang berbeda dari penelitian ini sehingga dapat merekomendasikan desain laporan keuangan dengan Microsoft Access berdasarkan SAK EMKM yang dapat digunakan Oleh UMKM Lainnya.

\section{Daftar Pustaka}

Dey, Natalia. 2018. "Desain Akuntansi Usaha Kos-kosan Berdasarkan Standar Akuntansi Keuangan Entitas Mikro, Kecil dan Menengah (SAK EMKM) (Studi Kasus pada Usaha Kos-kosan El Shadai Politeknik).Skripsi. Politeknik Negeri Manado

Ikatan Akuntan Indonesia. 2018. Standar Akuntansi Keuangan entitas Mikro, Kecil, dan Menengah (SAK EMKM). Dewan Standar Akuntansi Keuangan. Jakarta

Rusmawan, Uus. 2019. Teknik Penulisan Tugas Akhir dan Skripsi Pemrograman. Penerbit PT. Elex Media Komputindo. Jakarta

Sarimbungan, Samuel Corneles. 2018. "Desain Aplikasi Kasir Berbasis Microsoft Access Pada Boulevard D'Coffee Aceh Manado". Skripsi. Politeknik Negeri Manado

Setiorini, Kusumaningdiah Retno. 2018. Kualitas Sistem Informasi Akuntansi. Penerbit Elmatara. Yogyakarta

Shonhadji, Nanang dkk. 2017. "Penerapan Penyusunan Laporan Keuangan Pada Usaha Kecil Menengah Berdasarkan SAK EMKM di Surabaya". Jurnal. STIE Perbanas Surabaya. 1(1), 344-348

Soemarsono. 2004. Akuntansi Suatu Pengantar. Penerbit Salemba Empat. Jakarta.

Sugiono, Areif. 2010. Akuntansi dan Pelaporan Keuangan untuk Bisnis Skala Kecil dan Menengah. Penerbit PT. Grasindo. Jakarta

Sugiono. 2017. Metode Penelitian Kuantitatif, Kualitatif dan R\&D. Penerbit PT. ALFABETA. Bandung

Sujarweni, V. Wiratna. 2019. Akuntansi UMKM. Penerbit PT. Pustaka Baru. Yogyakarta

Sunyoto. Danang. 2013. Metode Penelitian Akuntansi. Penerbit PT. Refika Aditama. Yogyakarta

Suryana. 2010. Metodologi Penelitian: Model Praktis Penelitian Kuantitatif dan Kualitatif. Bahan ajar perkuliahan. Universitas Pendidikan Indonesia

Tim EMS. 2014. Microsoft Access untuk Pemula. Penerbit PT. Elex Media Komputindo. Jakarta

Tri Febri Asriyani. 2019. "Program Aplikasi Sistem Informasi Akuntansi Laporan Keuangan Berdasarkan SAK EMKM Menggunakan Microsoft Access 2019 (Studi Kasus Pada Rumah Makan Mandeh Duri).” Tugas Akhir. Politenik Negeri Bandung

Tumbelaka, Regina Natasia. 2018. "Desain Akuntansi Usaha Mikro Kecil dan Menengah berdasarkan Standar Akuntansi Keuangan Entitas Mikro Kecil dan Menengah (Studi Kasus Café Chamar di Kawangkoan)". Skripsi. Politenik Negeri Manado 
Undang-Undang No 20 Tahun 2008 Tentang Usaha, Mikro Kecil dan Menengah (UMKM)

Yuhaida, Eka Yulia Sofia. 2019.” Perancangan Akuntansi Berbasis Excel Sesuai SAK EMKM Pada Counter Laris Cell Jombang". Skripsi. Universitas Islam Negeri Sunan Ampel. 